\title{
Kompetensi Komunikasi Fasilitator Kecamatan dalam Program Nasional Pemberdayaan Masyarakat Mandiri Pedesaan di Langkat
}

\section{Communication Competency of Kecamatan Facilitator in National Program for Empowerment of Rural Mandiri Communities in Langkat}

\author{
Syamsul Adha* \\ Magister Ilmu Komunikasi, Fakultas Ilmu Sosial dan Ilmu Politik \\ Universitas Sumatera Utara, Indonesia \\ *Email: syamsul_adha@yahoo.com
}

\begin{abstract}
Abstrak
Penelitian ini berjudul kompetensi komunikasi fasilitator kecamatan dalam program nasional pemberdayaan masyarakat mandiri pedesaan (PNPM-MP) di Kabupaten Langkat. Tujuan penelitian ini adalah untuk mengetahui kompetensi komunikasi Fasilitator dan aktivitas program pemberdayaan masyarakat dalam PNPM-MP di Kabupaten Langkat. Metode yang digunakan penelitian ini adalah metode korelasional. Populasi pada penelitian ini adalah fasilitator dan pengelola anggaran PNPM-MP pada tahun 2014 di Kecamatan Secanggang yang berjumlah 1310 orang. Penarikan sampel menggunakan rumus Slovin dan didapat sampel penelitian ini berjumlah 93 responden. Teknik analisa data yang digunakan dalam penelitian ini adalah analisa tabel tunggal, analisa tabel silang, dan uji hipotesis. Dari uji hipotesis koefisien korelasi tata jenjang (Rank-Order Corelation) Spearman diperoleh hasil 0.411 untuk kompetensi komunikasi fasiltator. Dengan demikian dapat disimpulkan bahwa hipotesis dalam penelitian ini diterima dan hubungannya signifikan. Hasil penelitian ini menyimpulkan bahwa Kompetensi komunikasi fasilitator kecamatan pada program PNPM-MP di kecamatan Secanggang dapat dilihat dari bagaimana fasilitator menjalin hubungan yang baik dengan masyarakat, memobilisasi setiap kelompok masyarakat, melakukan perubahan, menentukan prioritas, melakukan pelatihan, dan pengembangan lembaga desa, dimana hal tersebut mampu meningkatkan kesejahteraan masyarakat, meningkatkan kinerja institusi lokal, dan meningkatkan kinerja pemerintah daerah dalam upaya penanggulangan kemiskinan
\end{abstract}

Kata Kunci: Kompetensi Komunikasi, Fasilitator, Pemberdayaan Masyarakat

\begin{abstract}
This research entitled competence communication facilitators subdistrict in the national program of rural community empowerment (PNPM-MP) of Langkat Regency. The purpose of this research is to know the communication competence of Facilitators and community empowerment program activities within the PNPM-MP in Langkat Regency. The method used in this research is correlation method. The population in this research is the facilitator and Manager a budget of PNPM-MP in 2014 in district of Secanggang, the population in this research as much as 1310. Withdrawal of samples using the sample Slovin formula and obtained the study amounted to 93 the respondent. Data analysis technique used in this research is single table analysis, cross table analysis, and hypothesis test. Of the hypothesis a correlation coefficient of the level of (rank-order corelation) the spearman the results 0.411 to competence communication fasiltator. Thus can be concluded that hypothesis in research is accepted and its relation significant. The results of this study conclude that the communication competence of facilitators in the PNPM-MP program in Secanggang sub-district can be seen from how the facilitator maintains good relationships with the community, mobilizes every community, changes, priorities, training and development of village institutions, able to improve the welfare of the community, improve the performance of local institutions, and improve the performance of local governments in poverty reduction efforts.
\end{abstract}

Keywords: Community Empowerment, Facilitator, Communication Competence

How to Cite: Adha, S., (2017), Kompetensi Komunikasi Fasilitator Kecamatan dalam Program Nasional Pemberdayaan Masyarakat Mandiri Pedesaan di Langkat, SIMBOLIKA, 3 (1): 55-65 


\section{PENDAHULUAN}

Program Nasional Pemberdayaan Masyarakat Mandiri adalah program nasional penanggulangan kemiskinan terutama yang berbasis pemberdayaan masyarakat diluncurkan oleh Presiden Susilo Bambang Yudhoyono pada tanggal 30 April 2007 di Kota Palu, Sulawesi Tengah. Program ini merupakan scaling up (pengembangan yang lebih luas) dari program-program penanggulangan kemiskinan di era sebelumnya. Sebelumnya telah banyak programprogram penanggulangan kemiskinan di Indonesia yang menggunakan konsep pemberdayaan masyarakat (community development) sebagai pendekatan operasionalnya. Dimulai dari program yang paling terkenal di masa Pemerintahan Orde Baru, program IDT (Inpres Desa Tertinggal). Kemudian Program Pengembangan Kecamatan (PPK) yang dilaksanakan Departemen Dalam Negeri 1998, Program Penanggulangan Kemiskinan di Perkotaan (P2KP) yang dilaksanakan Departemen Pekerjaan Umum 1999, Pemberdayaan Ekonomi Masyarakat Pesisir (PEMP) yang dilaksanakan Departemen Kelautan dan Perikanan, KUBE (Kelompok Usaha Bersama) yang dilaksanakan Departemen Sosial, dan lainnya. Program-program tersebut berjalan sendiri-sendiri menurut kebijakan Departemen yang bersangkutan, tidak terintegrasi, parsial dan sektoral.

PNPM Mandiri Pedesaan mengadopsi sepenuhnya mekanisme dan prosedur Program Pengembangan Kecamatan (PPK) yang telah dilaksanakan sejak 1998-2007. Program pemberdayaan masyarakat ini dapat dikatakan sebagai program pemberdayaan masyarakat terbesar di tanah air, bahkan terbesar di dunia. Program ini memprioritaskan kegiatan bidang infrastruktur desa, pengelolaan dana bergulir bagi kelompok perempuan, kegiatan pendidikan dan kesehatan bagi masyarakat di wilayah pedesaan. Program ini terdiri dari tiga komponen utama, yaitu : a) Dana BLM (Bantuan Langsung Masyarakat, b) Dana Operasional Kegiatan (DOK) dan c) pendampingan masyarakat yang dilakukan oleh para fasilitator pemberdayaan, fasilitator teknik dan fasilitator keuangan.

Pelaksanaan PNPM Mandiri Pedesaan berada di bawah binaan Direktorat Pemberdayaan Masyarakat dan Desa (PMD), Departemen/Kementrian Dalam Negeri. Program ini didukung dengan pembiayaan yang bersumber dari alokasi Anggaran Pendapatan dan Belanja Negara (APBN), alokasi Anggaran Pendapatan dan Belanja Daerah (APBD), partisipasi dari Corporante Social Responcibility (CSR) dan hibah serta pinjaman dari sejumlah lembaga dan negara pemberi bantuan dibawah koordinasi Bank Dunia.

Komunikasi merupakan bagian tidak terpisahkan dari pendekatan partisipatif. Bila pembangunan memiliki relevansi dengan masyarakat yang paling membutuhkan maka komunikasi harus dapat dimulai untuk menguraikan masalah yang ada. Bagi sebagian besar, mereka belum mampu melakukan komunikasi antar partisipan karena kurangnya partisipasi sejati, mengingat dalam strategi pembangunan hal tersebut seolah-olah dibentuk bertujuan memperbaiki permasalahan.

Keberadaan partisipan aktif dapat mengkomunikasian pembangunan seperti yang diinginkan, komunikasi berbasis berbagi pengetahuan dan setara dapat menjadi salah satu jawaban 
untuk pembangunan di negara berkembang. Model ini secara kultural dapat diterima dan secara praktis jauh lebih relevan, karena menjanjikan forum yang lebih demokratis dalam berkomunikasi (Harun dan Ardianto, 2011).

Komunikasi

pembangunan

partisipatif sebagai pendekatan alternatif dapat dipandang sebagai "sarana ampuh" untuk memfasilitasi proses-proses partisipatif bila sejalan dengan dinamika pembangunan di tingkat lokal. Proses partisipatif yang dimaksud adalah adanya partisipasi komunitas. PNPM sendiri terdiri dari beberapa bagian salah satunya adalah Program Nasional Pemberdayaan Masyarakat Mandiri Pedesaan (PNPMMP).

Fasilitator Kecamatan sebagai garda terdepan yang berhadapan dan berinteraksi dengan masyarakat untuk melakukan proses pendampingan masyarakat dalam mengikuti atau melaksanakan PNPM Mandiri Pedesaan. Peran fasilitator kecamatan adalah memfasilitasi masyarakat dalam setiap tahapan PNPM Mandiri Pedesaan. Fasilitator Kecamatan dan penyuluh juga harus memiliki kompetensi komunikasi.

Kompetensi komunikasi adalah istilah yang kompleks, kaya struktur internal dan eksternal. Kualitas kompetensi komunikasi tertentu diperlukan tidak hanya dalam interaksi sosial di tingkat interpersonal, tetapi juga di tingkat organisasi dan masyarakat, serta untuk pertukaran antarbudaya (Rickhet, et al., 2008).

Fasilitator Kecamatan dan penyuluh tidak secara langsung merupakan sumber informasi utama, karena pada dasarnya mereka adalah penyampai informasi berikutnya yang dalam model komunikasi dikenal dengan nama two steps flow communication. Banyak aspek yang ingin dilihat dari fasilitator Kecamatan dalam program PNPM-MP, namun peneliti sangat tertarik dari segi kompetensi komunikasi si fasilitator.

PNPM-MP secara langsung telah mampu melahirkan fakta bahwa pembangunan saat ini tidak hanya bersifat fisik semata tetapi sudah pembangunan seutuhnya. Ini merupakan pembuktian bahwa bangsa ini peduli dengan masyarakatnya yakni lewat penyataan: "PNPM-MP adalah program yang menjunjung tinggi falsafah "dari, oleh dan untuk rakyat".

Program PNPM-MP selama pelaksanaanya menghasilkan hasil kinerja yang bagus dikarenakan pendamping desa (orang PNPM dan PNPM-MP dibawah kementerian dalam negeri) membuat penulis tertarik untuk meneliti karena beranjak pada permasalahan bahwa pada masing-masing wilayah yang melaksanakan program tersebut memiliki Fasilitator Kecamatan. Penulis mengamati apakah ada pengaruh kompetensi komunikasi Fasilitator Kecamatan di terhadap pemberdayaan masyarakat dalam PNPM-MP. Apakah ada faktor lain yang mempengaruhi, secara positif ataupun negatif dan juga mengeksplorasi apakah para Fasilitator tersebut memiliki kompetensi komunikasi.

Penelitian ini terinspirasi dari beberapa penelitian sebelumnya yakni: Penelitian yang dilakukan oleh Pipsa Purhonen (2012) yang berjudul Interpersonal Communication Competence and Collaborative Interaction in SME Internationalization (Komunikasi Interpersonal Kompetensi dan Kolaborasi 
Interaksi di Internasionalisasi UKM), Disertasi di Department of Communication, University of Jyväskylä, Finlandia. Temuan mengungkapkan keragaman hubungan kolaboratif dari kemitraan baru dibentuk untuk jangka panjang hubungan berkelanjutan selama beberapa tahun. Hubungan antara perwakilan UKM dan organisasi perantara yang biasanya dimulai dalam konteks kerja seperti proyek, tugas, atau pertemuan bisnis, atau melalui jaringan bisnis dan perantara formal. Namun, hasil menunjukkan bahwa hubungan kolaboratif juga dapat dibentuk secara informal melalui teman atau saudara.

Woraporn Limpornpugdee, Brian D Janz dan Sandra M Richardson pada (2009) berjudul Communication Competence Factors as Moderators to the Relationship between User Participation and Information Quality (Faktor Kompetensi Komunikasi sebagai Moderator Hubungan Partisipasi Pengguna dan Kualitas Informasi), untuk melihat faktor-faktor yang mempengaruhi kualitas informasi dari sistem dengan memanfaatkan partisipatif pengambilan keputusan teori dan kerangka kompetensi komunikasi. Hasil penelitian menunjukkan bahwa terdapat hubungan positif antara partisipasi pengguna dan kualitas informasi. Analisis regresi moderated menunjukkan bahwa pengalaman kerja pengguna ' negatif moderator hubungan, sementara komponen kompetensi komunikasi positif moderator itu.

Penelitian yang dilakukan Mubarak (2010) berjudul Evaluasi Pemberdayaan Masyarakat Ditinjau dari Proses Pengembangan Kapasitas pada Kegiatan PNPM Mandiri Perkotaan di Desa Sastrodirjan Kabupaten Pekalongan. Dari hasil penelitian diketahui bahwa kegiatan pengembangan kapasitas, masyarakat di Desa Sastrodirjan telah dilaksanakan sesuai dengan prinsip pemberdayaan dan telah berhasil mengubah tingkat kesadaran masyarakat serta meningkatkan pemahamannya untuk berperan dalam pembangunan di komunitasnya. Temuan yang didapatkan adalah perubahan kesadaran masyarakat tidak berhubungan dengan usia responden, tingkat pendidikan dan perannya dalam PNPM, namun memiliki hubungan dengan jenis kelamin, dimana peran dan keterlibatan perempuan masih rendah dan belum cukup optimal dalam mendukung pembangunan di tingkat komunitas. Masyarakat Desa Sastrodirjan telah menyadari konsep pemberdayaan dan mengerti untuk menggunakannya bagi kepentingan komunitasnya, namun untuk menuju tahapan pembiasaan masih membutuhkan pembelajaran yang lebih banyak sehingga mereka benar-benar siap untuk bertangggungjawab secara penuh dalam pengelolaan pembangunan komunitasnya. Masyarakat juga telah siap untuk melanjutkan program pemberdayaan yang selama ini telah berjalan, meskipun secara mandiri hal tersebut belum dapat dilaksanakan sendiri oleh masyarakat dan masih membutuhkan pendampingan yang intensif dari pihak luar serta bantuan pendanaan secara kontinyu.

$\begin{array}{cl}\text { Sagala } & (2009) \text { berjudul Evaluasi } \\ \text { Program } & \text { Nasional }\end{array}$ Masyarakat Mandiri Pedesaan (PNPM-MP) terhadap Pengembangan Sosio-ekonomi dan Kesejahteraan Masyarakat di Kecamatan Balige Kabupaten Toba Samosir. PNPM-MP di Kecamatan Balige belum sepenuhnya dilaksanakan secara 
baik, sarana dan prasarana fisik dibangun belum menjadi prioritas utama. Disebabkan tidak jelas manfaat serta pemanfaatnya. Tingkat partisipasi masyarakat belum datang dari hati nurani tetapi masih digerakkan oleh tokoh-tokoh (informal leader) yang ada di desa tersebut. Dampak PNPM-MP terhadap kondisi sosio-ekonomi pendapatan dan pendidikan masyarakat sebelum dan sesudah adanya PNPM-MP berbeda nyata secara positif. Demikian juga pendapatan dan pendidikan masyarakat yang tidak menerima PNPM-MP juga signifikan atau berbeda nyata. Justru kenaikan pendapatan dan pendidikan masyarakat yang menerima Program PNPM-MP lebih rendah, karena umumnya masyarakatnya miskin, tingkat kualitas sumberdaya manusia rendah dan secara umum pekerjaan mereka adalah petani. Dengan adanya program PNPM-MP di Kecamatan Balige menciptakan peluang kerja kepada masyarakat.

Kompetensi komunikasi adalah kemampuan seorang individu untuk berkomunikasi secara tepat dan efektif sesuai dengan situasi sosialnya, yang meliputi kemampuan individu dalam bertindak, serta pengetahuan dan motivasi yang dimiliki individu. Brian Spitzberg dan William Cupach (dalam Greene dan Burleson, 2003; Payne, 2005) menyatakan terdapat tiga komponen kompetensi komunikasi, yaitu, knowledge, motivation, skills. Soler dan Jordan (2007), berdasarkan hasil penelitiannya mengungkapkan bahwa terdapat beberapa faktor yang dapat mempengaruhi kemampuan atau kompetensi seorang, yaitu: Acquisition Context, a) Usia saat pertama kali mempelajari Bahasa; b) Frekuensi penggunaan bahasa kedua; c) Jenis kelamin; d) Usia; e) Level pendidikan .

$$
\text { Komunikasi Pembangunan }
$$

merupakan suatu kegiatan komunikasi yang memiliki tujuan luas dan jauh ke depan untuk terjadinya perubahan besarbesaran dalam mental dan perilaku manusia, karena itu, ia menuntut setiap warga masyarakat untuk mengambil keputusan tentang kesediaannya melakukan perubahan-perubahan yang diperlukan demi perbaikan mutu hidup atau kesejahteraan dirinya sendiri, keluarga dan masyarakatnya dalam arti yang lebih luas (Mardikanto, 2010).

Komunikasi Pembangunan dapat dirumuskan (Mardikanto, 2010) sebagai: "Proses interaksi seluruh warga masyarakat, untuk tumbuhnya kesadaran, kemauan, dan kemampuan menggerakkan dan mengembangkan partisipasi masyarakat dalam proses perubahan terencana demi perbaikan mutu-hidup segenap warga masyarakat secara berkesinambungan, dengan menggunakan teknologi atau menerapkan inovasi yang sudah terpilih."

Mardikanto

warga masyarakat adalah semua stakeholders (pemangku kepentingan) pembangunan yang meliputi: aparat pemerintah, tokohtokoh (informal) masyarakat, pekerja sosial, aktivitas LSM, dan perseorangan atau kelompok/organisasi sosial.

Dalam praktek komunikasi pembangunan, sumber atau komunikator diperankan oleh fasilitator atau agenperubahan/change agent). Lippit dan Rogers (1958) menyebut "fasilitator" itu sebagai "agen perubahan (change agent)", yaitu seseorang yang atas 'nama pemerintah atau penyelenggara komunikasi pembangunan berkewajiban 
untuk mempengaruhi proses pengambilan keputusan yang dilakukan oleh (calon) penerima manfaat dalam kegiatan pembangunan.

Fasilitator adalah pekerja profesional sebagai pelaksana program/ kegiatan demi keberhasilan dan atau tercapainya tujuantujuan komunikasi pembangunan.

Berdasarkan status dan lembaga tempatnya berkerja, fasilitator dibedakan dalam (UU No. 16 Tahun 2006): Pegawai Negeri Sipil, fasilitator swasta, fasilitator swadaya. Fasilitator harus mampu mengorganisasikan, memotivasi dan menggerakkan, melakukan peran bantuan dan advokasi kebijakan yang diperlukan penerima manfaatnya dan mampu menjadi jembatan penghubung antara pemerintah atau penyelenggara komunikasi pembangunan yang diwakili dengan masyarakatnya.

Berlo (1961) mengemukakan 4 (empat) kualifikasi yang harus dimiliki setiap fasilitator mencakup: Kemampuan berkomunikasi, Sikap fasilitator yang menghayati dan bangga terhadap profesinya, Meyakini bahwa inovasi yang disampaikan itu telah teruji kemanfaatannya, Menyukai dan mencintai masyarakat, Kemampuan /penguasaan pengetahuan tentang: Isi, fungsi, manfaat, dan nilai-nilai yang terkandung dalam inovasi yang disampaikan. Latar belakang dan keadaan masyarakat penerima manfaatnya,

Segala sesuatu yang seringkali menyebabkan warganya suka atau tidak menghendaki terjadinya perubahan dan segala sesuatu yang menyebabkan masyarakat seringkali cepat/lambat mengadopsi inovasi.

Fasilitator Kecamatan adalah pendamping masyarakat dalam mengikuti atau melaksanakan PNPM Mandiri Pedesaan. Tugas Pokok dan Fungsi
Fasilitator Kecamatan dalam program PNPM Mandiri Pedesaan berdasarkan penjelasan V PTO PNPM-MP termaktub di Departemen dalam negeri tahun 2008.

Jim Ife \& Frank Tegoriero (2008), ada enam dimensi pengembangan atau pemberdayaan masyarakat dan kesemuanya berinteraksi satu sama lain dalam bentuk yang kompleks, yaitu: 1) Pengembangan social, 2) Pengembangan ekonomi, 3) Pengembangan politik, 4) Pengembangan budaya, 5) Pengembangan lingkungan, 6) Pengembangan personal/ spiritual

PNPM-MP merupakan koreksi terhadap sistem pembangunan terdahulu yang pada umumnya bersifat sentralistik. PNPM-MP telah menjadi bagian dari tahapan perencanan dan pelaksanaan pembangunan di kabupaten Langkat sejak tahun 2007 dan telah melaksanakan berbagai kegiatan pembangunan fisik maupun non fisik dan telah melibatkan hampir seluruh masyarakat di 23 (dua puluh tiga) kecamatan yang ada di Kabupaten Langkat. Konsep pelaksanaan PNPM-MP menekankan pada strategi pembangunan bottom up yakni meletakkan masyarakat sebagai pelaku utama pembangunan. Dengan strategi ini masyarakat menjadi motor utama pembangunan. Salah satu contoh keberhasilan PNPM-MP adalah Kecamatan Secanggang yang menerima PNPM Mandiri Pedesaan yang pelaksanaannya telah dimulai pada tahun 2007 dan masih berjalan sampai sekarang. Kecamatan Secanggang dianggap berhasil dalam pelaksanaan PNPM-MP karena memiliki progress yang cukup baik dilihat dari pelaksanaan kegiatan yang sesuai agendaagenda yang telah direncanakan baik dalam kegiatan pemberdayaan 
masyarakatnya, kegiatan pembangunan fisik lingkungannya maupun kegiatan simpan pinjam khusus perempuan.

\section{Model Teoritis}

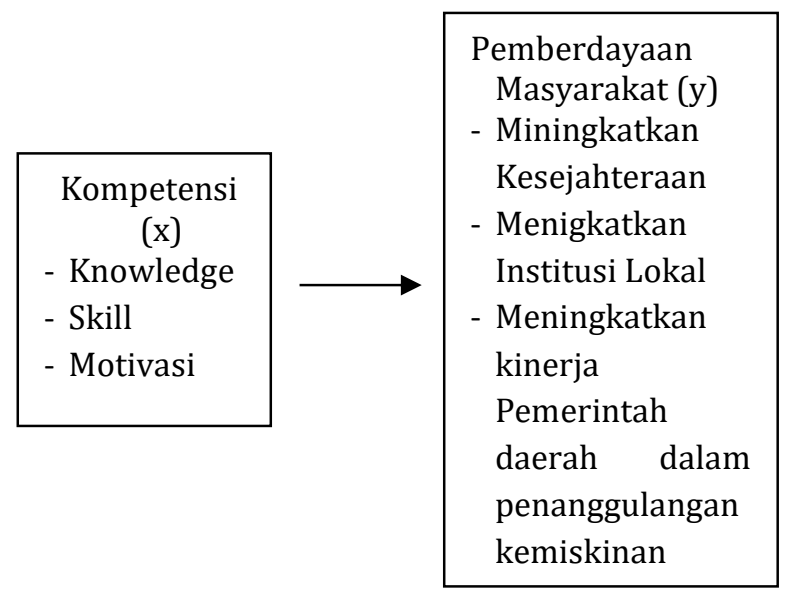

\section{Hipotesis}

Hipotesis Ho: Kompetensi Komunikasi Fasilitator Kecamatan dalam program PNPM-MP tidak berpengaruh terhadap pemberdayaan masyarakat

Hipotesis Ha: Kompetensi Komunkasi Fasilitator Kecamatan dalam program PNPM-MP berpengaruh terhadap pemberdayaan masyarakat.

\section{METODE PENELITIAN}

Penelitian ini menggunakan metode penelitian kuantitatif korelasional. Teknik pengambilan datanya yaitu dengan kuesioner untuk mengukur data variabel $\mathrm{X}$ (kompetensi komunikasi fasilitator) dan variabel Y (pemberdayaan masyarakat) serta variabel intervening yang kemudian akan diolah dengan instrumen penelitian. Kemudian kontribusi varians variabel dapat dicari menggunakan teknik statistik dengan menghitung besarnya koefisien determinasi.
Intensitas hubungan dalam penelitian korelasi diukur dengan mempergunakan prosedur matematis dengan menyatakan koefisien korelasi, yang dapat bergerak dari -1.00 sampai dengan $+1,00$.

Populasi pada penelitian ini adalah fasilitator dan pengelola anggaran PNPMMP pada tahun 2014 di Kecamatan Secanggang, sebanyak 1310 (Data PNPM Kecamatan Secanggang 31 Desember 2014). Sampel dalam penelitian ini berjumlah 93 responden. Penarikan sampel dalam penelitian ini menggunakan teknik penarikan sampel Slovin (Sugiyono, 2001).

\section{HASIL DAN PEMBAHASAN}

Proses pengumpulan data dimulai pada tanggal 27 Maret-15April 2016, peneliti menyebarkan kuesioner kepada responden. Peneliti dibantu tenaga enumerator yang sudah peneliti berikan pemahaman terlebih dahulu. Peneliti menggunakan tiga orang tenaga enumerator untuk memudahkan pengisian. Kuesioner berisi 26 pertanyaan tertutup dan 2 pertanyaan terbuka, terdiri dari 5 pertanyaan untuk karakteristik responden, 21 pertanyaan mengenai pengaruh kompetensi komunikasi fasilitator Kecamatan dalam program PNPM-MP terhadap pemberdayaan masyarakat di kecamatan Secanggang. Saat responden akan menjawab pertanyaan, enumerator juga menjelaskan pertanyaan-pertanyaan yang kurang dimengerti responden dan memastikan agar tidak ada satu pun pertanyaan yang terlewatkan. Selanjutnya pengumpulan data sekunder melalui buku-buku kepustakaan yang ada, data-data dari lapangan dan observasi. 
Setelah peneliti selesai mengumpulkan data dari 93 responden, maka pengolahan data akan dimulai. Tahap pengolahan data tersebut adalah: 1) Penomoran Kuesioner, 2) Editing, 3) Coding, 4) Inventarisasi Variabel,

\section{Tabel 1. Uji Hipotesis}

\begin{tabular}{|c|c|c|c|c|}
\hline \multicolumn{5}{|c|}{ Correlations } \\
\hline & & & $\begin{array}{l}\text { Kompete } \\
\text { nsi }\end{array}$ & $\begin{array}{l}\text { Pemberdaya } \\
\text { an } \\
\text { masyarakat }\end{array}$ \\
\hline \multirow{6}{*}{$\begin{array}{l}\text { Spear } \\
\text { man's } \\
\text { rho }\end{array}$} & \multirow{3}{*}{$\begin{array}{l}\text { Kompet } \\
\text { ensi }\end{array}$} & \begin{tabular}{|l} 
Correlation \\
Coefficient
\end{tabular} & 1,000 & $411^{* *}$ \\
\hline & & $\begin{array}{l}\text { Sig. } \\
\text { tailed) }\end{array}$ & & ,000 \\
\hline & & $\mathrm{N}$ & 93 & 93 \\
\hline & \multirow{3}{*}{$\begin{array}{l}\text { Pember } \\
\text { dayaaan } \\
\text { masyara } \\
\text { kat }\end{array}$} & $\begin{array}{l}\text { Correlation } \\
\text { Coefficient }\end{array}$ & $411^{* *}$ & 1,000 \\
\hline & & $\begin{array}{l}\text { Sig. } \\
\text { tailed) }\end{array}$ &, 000 & \\
\hline & & $\mathrm{N}$ & 93 & 93 \\
\hline
\end{tabular}

**. Correlation is significant at the 0.01 level (2tailed).

Berdasarkan hasil korelasi Spearman pada tabel 1, diketahui korelasi koefisien Spearman (rho) adalah 0,411. Berdasarkan skala Guilford, hasil 0,411 menunjukkan hubungan yang cukup berarti. Tanda korelasi pada koefisien korelasi menghasilkan $+0,411$ menunjukkan arah hubungan yang sama antara variabel X dan variabel Y. Berarti semakin tinggi kompetensi komunikasi fasilitator maka semakin baik pemberdayaan masyarakat di Kecamatan Secanggang begitu pun sebaliknya.

Signifikansi hasil korelasi dapat dilihat berdasarkan perbandingan nilai probabilitas dan tanda $* / * *$ (flag of significant) diberikan SPSS. Jika probabilitas $>0,05$, maka Ha ditolak, jika probabilitas < 0,05 maka Ha diterima. Pada bagian output korelasi di atas terlihat pasangan data yang berkorelasi secara signifikan, antara kompetensi dan pemberdayaan masyarakat (probablilitas
0,01 yang lebih kecil dari 0,05 atau 0,01 < $0,05)$. Hasil uji hipotesis pada kompetensi komunikasi program PNPM-MP di Kecamatan Secanggang terhadap kemampuan fasilitator adalah 0,411. Sesuai kaidah dalam Spearman rs koefisien bahwa jika rs $>0$ maka hipotesis diterima. Signifikan korelasi diketahui dari probabilitas yang lebih kecil dari 0,05 $(0,01<0,05)$ dan tanda ${ }^{* *}$ (flag of significant) yang menunjukkan kedua variabel berkorelasi secara signifikan, maka hubungannya adalah signifikan. Hipotesis dalam penelitian ini diterima dan hubungannya signifikan.

Kompetensi komunikatif adalah suatu penekanan pada kefasihan dan penggunaan bahasa yang berterima, merupakan tujuan pembelajaran. Akurasi (ketepatan) tidak diukur secara abstrak, tetapi dalam konteks. Secara ringkas Hymes (1972), menyebut empat faktor yang membangun dan menjadi ciri penanda kompetensi komunikatif, yaitu kegramatikalan, keberterimaan, keterlaksanaan.

Penelitian ini mencoba untuk melihat kompetensi komunikasi dari para fasilitator dalam menjalankan tugasnya untuk mencapai tujuan mensejahterakan masyarakat, meningkatkan kinerja institusi lokal, dan meningkatkan kinerja pemerintah. Kemampuan komunikasi fasilitator pada kecamatan secanggang dilakukan pada beberapa bagian dimulai dari motivasi meningkatkan kinerja pemerintah, kemampuan menjalin hubungan, kemampuan pentingnya menunjukkan perubahan, kemampuan menentukan prioritas, kemampuan memobilisasi, kemampuan menyelenggarakan pelatihan, kemampuan 
mengembangkan kelembagaan, dan kemampuan memimpin.

Hasil dari penelitian tentang kompetensi komunikasi fsilitator pada program PNPM-MP dalam meningkatkan kesejahteraan dan meningkatkan kinerja pemerintah lokal pada Kecamatan Secanggang, dari sebaran data 93 responden menyatakan kompetensi komunikasi fsilitator dalam meningkatkan kesejahteraan dan meningkatkan kinerja pemerintah $73 \%$ responden menyatakan fsilitator mampu. Hasil menunjukkan kompetensi komunikasi yang dilakukan fasilitator di kecamatan secanggang tercapai.

Kompetensi komunikasi mencapai persentase $73 \%$ dilakukan dengan komunikasi kelompok, yaitu dengan membagi kelompok-kelompok yang berada pada masyarakat kecamatan Secanggang dimulai dari kelompok tani, ibu-ibu perwiritan, nelayan dan tokoh agama. Dilakukan agar mempermudah komunikasi yang dilakukan oleh fasilatator dalam mencapai tujuannya.

Cara lain adalah dengan menjalin hubungan yang baik dengan masyarakat, cara ini dilakukan dengan mendatangi tempat berkumpul masyarakat seperti warung, tempat ibadah, dan lainnya. Melalui cara tersebut mempermudahkan fasilitator dalam memobilisasi masyarakat untuk menjadikan tempat-tempat strategis untuk berkumpul. Dengan mengikuti setiap kegiatan yang dilakukan oleh masyarakat dengan cara membaur membuat fasilitator bisa melakukan diagnosa masalah apa yang terjadi sehingga fasilitator bisa memberikan inovasi-inovasi kemudian membuat acara secara formal untuk dimusyawarahkan dengan masyarakat tentang permasalahan yang terjadi sehingga dalam pengambilan keputusan fasilitator juga ikut memutuskan bagaimana keputusan yang lebih baik.

Fasilitator kecamatan melakukan perannya pada tahap sosialisasi, perencanaan, pelaksanaan dan pelestarian yang bertujuan mampu meningkatkan taraf hidup penerima manfaat program PNPM-MP sehingga tidak saja tergantung pada kondisi geografis tetapi sudah kepada aspek pengelolaan hasil. Pemberdayaan masyarakat yang dilakukan fasilitator dalam meningkatkan kinerja pemerintah pada aspek tertinggi ada pada pemberdayaan pengembangan spiritual dan lingkungan, dua aspek tersebut menjadi prioritas fasilitator dikarenakan Kecamatan Secanggang berhadapan langsung dengan selat malaka menjadikannya pusat peredaran narkoba yang membuat pemuda Secanggang menjadi target utama

Pengembangan yang dilakukan fasilitator dalam membangun aspek spiritual dan lingkungan dengan membaur kepada masyarakat Secanggang di tempat ibadah atau warung, ini diyakini bisa menjadi wadah bagi fasilitator dalam menyampaikan informasi kepada masyarakat untuk sama-sama menjaga lingkungan keberdaan mereka dari ancaman luar. Hasil penelitian menunjukkan bahwa ada kompetensi komunikasi fasilitator pada program PNPM-MP pada kecamatan Secanggang, sehingga bisa meningkatkan kesejahteraan masyarakat, meningkatkan kinerja pemerintah lokal, dan meningkatkan kinerja permerintah tercapai.

Peran fasilitator berbeda dengan peran penyuluh. Peran fasilitator pada 
program PNPM-MP lebih kepada mendidik dan membina masyarakat dengan segala kemampuan. Kemampuan yang dimiliki fasilitator pada program PNPM-MP yang sudah dikualifikasi dengan beberapa persyaratan, seperti kemampuan komunikasi, sikap fasilitator, kemampuan menguasai pengetahuan, dan mengetahui budaya masyarakat setempat.

Kemampuan

berkomunikasi

fasilitator, kemampuan dan ketrampilan fasilitator untuk beremphati dan berinteraksi dengan masyarakat penerima manfaatnya. Kemampuan berkomunikasi yang kemudian menimbulkan sikap fasilitator yaitu kualifikasi yang kedua, sikap fsilitator yang dimaksud adalah bagaimana fasilitator menghayati pekerjaannya sebagai fasilititator, meyakini dengan inovasi yang diberikan kepada masyarakat bahwa inovasi tersebut sudah teruji manfaatnya, juga menyukai dan mencintai masyarakat.

Kemampuan pengetahuan yang dimiliki fasilitator merupakan cara yang dilakukan fasilitator untuk memahami secara konseptual dan bisa memberikan pemahaman kepada masyarakat secara praktis dan mudah dipahami. Sasaran dari penyuluh lebih sempit dari pada fasilitator karena penyuluh lebih kepada konsultasi dan partisipasi, dimana konsultasi oleh para penyuluh hanya mencari solusi terhadap permasalahan, sedangkan partisipasi merupakan peran dari masyarakat secara aktif untuk memberikan informasi faktual tentang masalah yang dihadapi.

\section{SIMPULAN}

Kompetensi komunikasi fasilitator pada program PNPM-MP di kecamatan Secanggang dapat dilihat pada $\begin{array}{llr}\text { kemampuan } & \text { fasilitator } & \text { dalam } \\ \text { meningkatkan } & \text { kesejahteraan } & \text { pada }\end{array}$ masyarakat, meningkatkan kinerja pemerintah lokal, dan meningkatkan kinerja permerintah. Hal ini dapat dicapai dengan cara menjalin hubungan yang baik dengan masyarakat, memobilisasi setiap kelompok masyarakat, melakukakn perubahan, menentukan prioritas, melakukan pelatihan, dan mengembangkan lembaga desa. Aktivitas program pemberdayaan masyarakat dalam PNPM-MP di kecamatan Secanggang meliputi sosialisasi, perencanaan, pelaksanaan dan pelestarian dengan dimensi pengembangan sosial, ekonomi, politik, budaya, lingkungan dan pengembangan personal/spiritual. Pengaruh kompetensi komunikasi dari fasilitator kecamatan dalam pemberdayaan masyarakat pada PNPMMP di kecamatan Secanggang Kabupaten Langkat sangat signifikan dimana semakin tinggi kompetensi komunikasi fasilitator maka semakin baik pemberdayaan masyarakat di kecamatan Secanggang. Hal ini dapat dilihat dari bagaimana mereka mampu meningkatkan kesejahteraan masyarakat dan meningkatkan institusi lokal serta meningkatkan kinerja pemerintah daerah dalam penanggulangan kemiskinan karena peran fasilitator dalam menjalankan tugas dan fungsinya lebih kepada membina dan memberikan inovasi-inovasi baru kepada masyarakat dimana hal tersebut membutuhkan kompetensi komunikasi yang baik.

\section{DAFTAR PUSTAKA}

Berlo, D.K. (1961). "The Process of Communication". New York: Holt, Rinehart, and Waston. 
Brown, B.J., Mark E. Hanson, Diana M. Liverman, and Robert W. Merideth, Jr. (1987). "Global Sustainability: Toward Definition." Environmental Management 11 (6): 713-719.

Brown, H.D. (1987). Principles of Language Learning and Teaching. Englewood Cliffs, NJ: Prentice Hall.

Harun, R., and Elvinaro A., (2011). "Komunikasi Pembangunan Perubahan Sosial." Bandung: Rajawali Pers

http://www.hukumonline.com/pusatdata/

Hymes, D.H. (1972). "On Communicative Competence" In: J.B.Prideand J.Holmes (eds) Sociolinguistics. Selected Readings. Harmondsworth: Penguin, pp.269293.(Part2)

Limpornpugdee, Woraporn, Brian D Janz dan Sandra M Richardson (2009). Communication Competence Factors as Moderators to the Relationship between User Participation and Information Quality. Journal of Information Technology Management. Volume XX, Number 4

Lippit, R.J. Watson, and B. Westley. (1958). The Dynamics of Planned Change. NewYork: Harcourt, Brace and World, Inc.

Mardikanto, T., (2010). Komunikasi Pembangunan: Acuan bagi Akademisi, Praktisi dan Peminat Komunikasi Pembangunan. Surakarta: Sebelas Maret Universitas Press
Mubarak, Z., (2010), Evaluasi Pemberdayaan Masyarakat Ditinjau dari Proses Pengembangan Kapasitas pada Kegiatan PNPM Mandiri Perkotaan di Desa Sastrodirjan Kabupaten Pekalongan (Tesis). Semarang: Universitas Diponegoro

Purhonen, P, (2012). Interpersonal Communication Comptence and Collaborative Interaction in SME Internationalization (Disertasi). Finland. Department of Communication, University of Jyväskylä

Rickheit, G dan Strohner, H. (2008). Handbook of Communication Competence. Berlin: Mouton de Gruyter.

Sagala, O.D., (2009). Evaluasi Program Nasional Pemberdayaan Masyarakat Mandiri Pedesaan (PNPM-MP) Terhadap Pengembangan Sosio-Ekonomi Dan Kesejahteraan Masyarakat Di Kecamatan Balige Kabupaten Toba Samosir (Tesis), Medan: PWD USU.

Spitzberg, B.H. (2003). Methods of Interpersonal Skill Assessment. Dalam: Greene, O.B., \& Burleson, R. B. Handbook of Communication and Social Interaction Skill (pp. 93-134). New Jersey: Lawrence Erlbaum Associaties. 